\title{
Highland Influence on Chronic-bacterial-prostatitis and Developing-reason of Prostate-cancer, KSA
}

\author{
Sherifa Mostafa M. Sabra
}

Senior Const., Asst. Prof., Dr., Microbiology, Technology and Science Dept., Ranyah College, Taif University, KSA.

Corresponding Author: Sherifa Mostafa M. Sabra. Asst. Prof., Dr., Microbiology, Technology and Science Dept., Ranyah University College, Taif University, KSA

Received date: January 01, 2021; Accepted date: January 05, 2021; Published date: February 02,2021

Citation: Sherifa M. M. Sabra (2021) Highland Influence on Chronic-bacterial-prostatitis and Developing-reason of Prostate-cancer, KSA. J, Biotech. and Bioprocessing 2(2); DOI: 10.31579/2766-2314/022

Copyright: ( ) 2021, Sherifa Mostafa M. Sabra, This is an open access article distributed under the Creative Commons Attribution License, which permits unrestricted use, distribution, and reproduction in any medium, provided the original work is properly cited.

\begin{abstract}
This work was for "Highland (HL) Influence on Chronic-bacterial-prostatitis (CBP) and Developing-reason of Prostate-cancer (PCa), KSA"; the purpose was to determine CBP percentage at HL "Taif"; and influence of location factors on CBP percentage and indication of its developing-reason to causing PCa. It may negatively affected other body organs and may reach death of males' society, affected marital and community life. Used medical methods for cases taster (CsT) from patients were diagnosed as suffered from CBP. That were used direct and indirect identification by "CHROMagar Orientation Medium", and "VITEK 2 System (BioMerieux, France)". The pathogenic bacteria were found in more than a quarter of the CsT as (26 and $29 \%)$. That were Staphylococcous aureus (Staph. aureus), Escherichia coli (E. coli), Staphylococcous epidermidis (Staph. epidermidis) and Streptococcus species (Strept. Spp) in $(36.2 \%, 9.5 \%, 5.7 \%$ and 4.3\%) respectively. Pathogenic bacteria Staph. aureus represented more than third of CsT. E. coli represented tenth and it was dangerous for its transmission from UT and GT easily. Staph. epidermidis was present on the skin and represented normal flora can easily contaminated. Strept. Spp represented less than tenth, can transferred to prostate tissue and cause CBP leading to PCa. Concluded the CBP infection was present in HL and had developing-reason for $\mathrm{PCa}$, the conditions must followed to reduce it to prevent condition of turning into PCa. Recommended best periodic follow-up to detect CBP infection presence to protect against infection and its PCa developing-reason. Cases CBP infection must treated and PCa cases should not neglected or tolerated.
\end{abstract}

Key words: highland, chronic-bacterial-prostatitis, developing-reason, prostate-cancer, cases taster, pathogenic bacteria

\section{Abbreviation:}

CsT: Cases taster,

CBP: Chronic Bacterial Prostatitis,

CP: Chronic Prostatitis,

E.coli: Escherichia Coli,

EPs: Expresses Prostatic Secretions,

GT: Gastric Tract,

HL: Highland,

PCa: Prostate Cancer,

Staph. Aureus: Staphylococcous aureus,

Staph. Epidermiditis: Staphylococcous epidermiditis,

Strept. Spp: Streptococcus Spp.,

UT: Urinary Tract,

UTI: Urinary Tract Infection.

\section{Introduction}

$\mathrm{CBP}$ is an important contributing factor for $\mathrm{PCa}$ and / or its progression [1-2], that with detected bacterial species in PCa patients [3]. Prostate bacterial colonization were asymptomatic, CBP suspected to influence carcinogenesis, bacterial virulence as $E$. coli colibactin manipulated and changed host cell fates. Bacterial species had to interact, stimulate, repress immune responses, virulent or non-virulent bacteria created inflammatory microenvironment, CBP linked with carcinogenic processes in several layers [4]. One layer was infection-caused damage epithelial lining; this damage induced immune cell infiltration, and production proinflammatory cytokines and oxidative stress, infection combated cause nucleic acid damage, cell injury and death, bad cell fate [5]. An inflammatory microenvironment stimulated epithelial cell regeneration, creating proliferative inflammatory atrophy region; evolved into low and high-grade prostatic intraepithelial neoplasia, and prostate adenocarcinoma [6]. PCa associated with chronic inflammatory UT conditions as CBP [7], it associated with chronic UTI, as CBP understanding bacteria was vital in connecting dots in PCa pathogenesis [8]. E. coli, Staph. aureus and Staph. epidermidis isolated from acute and CBP [9], most common were Strept. Spp [10]. CBP created microenvironment contribute to prostate pathologies formation, UT and GT related to PCa. E. coli detected in prostatic tissue and contributed as initiator of prostate inflammation and $\mathrm{PCa}$ [11]. The UT bacteria connected to genitourinary malignancies, especially $\mathrm{PCa}$, was second cancer in males clear link between GT and UT bacteria and PCa risk [12]. PCa and peri-tumoral regions had higher Staph. Spp., but normal areas had Strept. Spp [13], they were the most predominant bacteria [14]. All patients per PCa had high Strept. Spp [15], so Staph. Spp and Strept. Spp 
recorded from PCa and benign cases [16], as enriched Strept. Spp in PCa [17]. E. coli and Staph. Spp found in various PCa degrees [18-19], also PCa tissue, invaded prostatic tissues and induced CBP [20]. PCa prostatic fluids had E. coli higher compared to urine [21]; it had virulence properties allowed colonization resulted in inflammation and tissue damaged [22]. E. coli from UT infiltrated the prostate and contributed to different inflammatory stimulated could change microenvironment roughly [23]. Trendy in 2000, KSA indicated PCa prevalence was still low [24], through 2001, data from KSA indicated PCa occurred at a lower rate in Arab populations than in populations in western countries [25]. Nevertheless, in 2008, in Riyadh, KSA revealed the PCa incidence rate was high and the disease progressive was $2.5 \%$ [26], so in 2015, over the last 15 years PCa accounted $13.5 \%$ [27].

The purpose of this research was to determine the CBP percentage at HL "Taif"; and the influence of location factors on CBP percentage and an indication of its developing-reason to causing PCa. It may negatively affected other body organs and may reach death of males society, which affected marital and community life.

\section{Methodology}

Samples preparation: The research purpose was clarified, then it was approved by "Private Health Center"; at HL, Taif, which included the Center owner, "Specialized Physician" and patients, that with did not mention their data. "Specialized Physician" collected CsT from patients were diagnosed as suffered from CBP. The steps were before sample collection, the urethral opening was cleaned with sterile saline, and bladder of all subjects was voided. The residual liquid in urethral opening was cleaned with sterile gauze. One sample of urethral secretions before prostate massage and one EPS sample after prostate massage were collected aseptically [28].

\section{Laboratory procedures:}

- Direct identification: Wet-mount: CsT drops on slides were added a drop of saline solution, so were covered and were examined by microscope [29]. Gram staining: CsT smears were prepared then were stained by Gram stain and were examined by microscope via oil emersion lens [30].

- Indirect identification: Isolation and identification: CsT were isolated and identified of pathogenic bacteria using "CHROMagar Orientation Medium", was valuable method naturally complete at a slight value [31]. For justification of pathogenic bacteria identification was used "VITEK 2 System (BioMerieux, France)", that was available in "Private Laboratory" with payment [32].

Statistical analysis understudy: The data were amassed, then was cast-off an Excel Statistics and was shaped tables and graphs were clean presentation the intensification work data [33].

\section{Results and discussion}

\begin{tabular}{|c|c|c|}
\hline Items & Bacterial & Non Bacterial \\
\hline Wet-mount & $26 \%$ & $74 \%$ \\
\hline Gram Staining & $29 \%$ & $71 \%$ \\
\hline
\end{tabular}

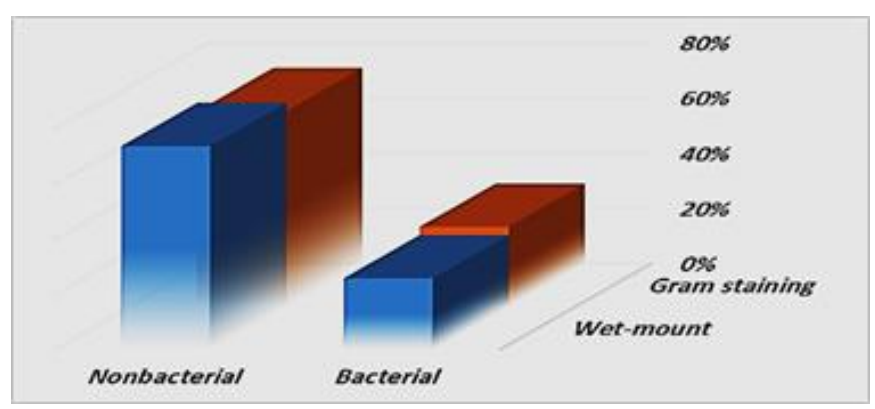

Table 1 and graph 1. Percentage of pathogenic bacteria by direct identification

Table 1 and graph 1 exposed percentage of pathogenic bacteria by direct identification; it was considered one of the fast and cheap methods. That may had a little inaccuracy, but it was considered one of the preliminary results of CsT. Effects of changing CsT ratios according to the method, the first method was a slight difference due to the size of the pathogenic bacteria. The movement did not help identification and may appeared very transparent. The staining method was considered one of the good, fast and cheap methods because it took a little time and stained cells, the result was evident through the microscope, and it preferred that the examiner be experienced in the work. It was shown in the CsT under study that the pathogenic bacteria were found in more than a quarter of the CsT as (26 and 29\%) [1-8]. As well indicated the extent of the presence of pathogenic bacteria and that it was very important causing CBP. This CBP infection could lead to aiding in the occurrence of PCa as initiation cancer factors and effect on physical body organs, may lead to its transmission to wives, and might males' death [24-27].

\begin{tabular}{|c|c|c|c|c|}
\hline \multirow[b]{2}{*}{ Items } & \multicolumn{2}{|c|}{ *Staph. Spp } & \multirow[b]{2}{*}{ *Strept. Spp } & \multirow[b]{2}{*}{ *E. coli } \\
\hline & *Staph. aureus & *Staph. epidermidis & & \\
\hline Percent & $36.2 \%$ & $5.7 \%$ & $4.3 \%$ & $9.5 \%$ \\
\hline
\end{tabular}

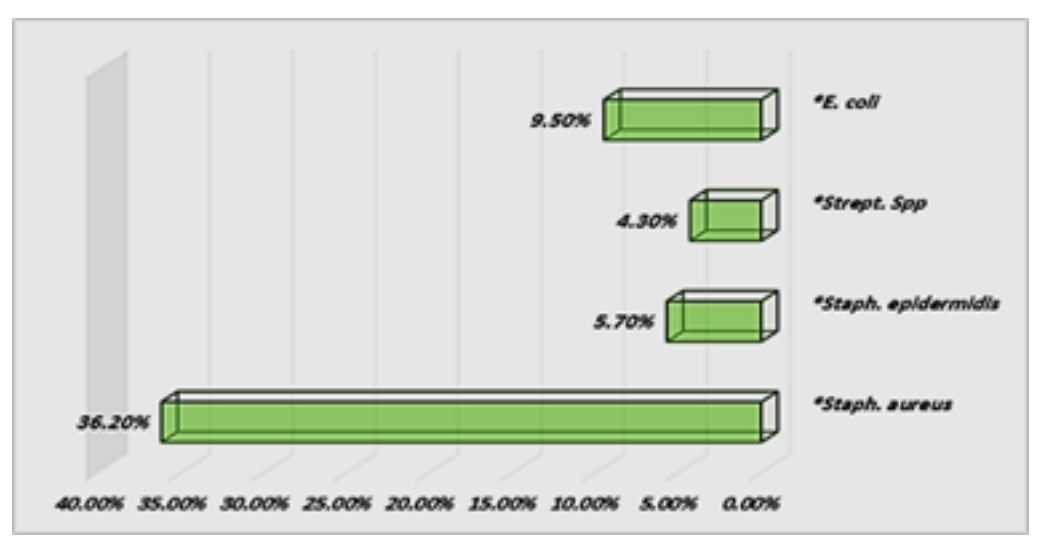

Table 2 and graph 2. Percentage of pathogenic bacteria by indirect identification 
Table 2 and graph 2 exposed percentage of pathogenic bacteria by indirect identification; it was found that all pathogenic bacteria from CsT in descending order from the top according to the percentage of each. That were (Staph. aureus, E. coli, Staph. epidermidis and Strept. Spp) in $(36.2 \%, 9.5 \%, 5.7 \%$ and $4.3 \%)$ respectively. The arrangement indicates the importance of the pathogenic bacteria to cause CBP. It was found that the pathogenic bacteria were Staph. aureus and represented more than a third of CsT. The second were E. coli represented the tenth and it was dangerous for its transmission from the UT and GT easily. The third Staph. epidermidis was less than a tenth, but it was present on the skin and represented the normal flora and can easily conveyed contamination which did not follow hygienic conditions. The latter Strept. Spp represented less than tenth, it is also presented in normal tissues, where it can transferred to prostate tissue and cause CBP leading to PCa [9-23]. One of the important points was the presence of pathogenic bacteria in cases of CBP infection, CBP causing one of the most dangerous in cases of PCa. Because of the pathogenic bacteria had ability to induce excitement of cells to transform from normal to carcinogen and lead to $\mathrm{PCa}$, which may lead to side effects on the body parts and ultimately male death [1-8]. Arab and Saudi males were considered to PCa less affected than European males due to the presence of religious beliefs, correct marital relations, Muslim religious milieu and lack of illegal relations. The role widespread and advanced "KSA Medical Services" reduced the CBP incidence and thus PCa and deaths of society males. In the cases under study, it was found that the influences, which were at HL, were found reduced infection than the rest of KSA [24-27]. It was important to reduce the pathogenic bacteria infection and the accompanying PCa death to avoid the causes that help in the presence of pathogenic bacteria infection of the prostate by doing the following to follow the personal hygiene regimens and during the marital relationship, not to make illegal relationships, to follow the religious legal systems. Males must go to the "Health Center" for treatment when symptoms or not symptoms appear, also do periodic inspection to ensure that there are no CBP infections or any secondary factors, to preserve the males and the society bravery [2427].

\section{Conclusion}

The CBP infection was present in HL and had developing-reason for PCa, therefore the conditions must followed to reduce CBP infection to prevent condition of turning into PCa.

\section{Recommendation}

Best periodic follow-up to detect CBP infection presence to protect against infection and its PCa developing-reason. Cases CBP infection must treated and PCa cases should not neglected or tolerated.

\section{Acknowledgment}

All thanks sent to all individual collaborated to produce this paper with God's help.

\section{Future Works}

After this paper, that would like to continue with the cases under study to follow the curative supervision and PCa progression

\section{Fundus}

That were from author.

\section{Conflict of interest}

There was none.

\section{Reference}

1. De Marzo, A., Platz, E., Sutcliffe, S., Xu, J., Gr€onberg, H. \& Drake, C., (2007) Inflammation in prostate carcinogenesis. Nat. Rev. Cancer. 7: 256-69.

2. Porter, C., Shrestha, E., Peiffer, L. \& Sfanos, K., (2018) The microbiome in prostate inflammation and prostate cancer. Prostate Cancer Prostatic Dis. 21: 345-354.

3. Eisenhofer, R., Minich, J., Marotz, C., Cooper, A., Knight, R. \& Weyrich, L., (2019) Contamination in low microbial biomass microbiome studies: issues and recommendations. Trends Micro. 27: 105-117.

4. Cai, T., Santi, R., Tamanini, I., Galli, I., Perletti, G. \& Bjerklund, J., (2019) Knowledge of the potential links between inflammation and prostate cancer. Int J Mol Sci. 20: 3833.

5. Yu, H., Lee, H., Herrmann, A., Buettner, R. \& Jove, R., (2014) Revisiting STAT3 signalling in cancer: new and unexpected biological functions. Nat Rev Cancer, 14: 736-46.

6. Khandrika, L., Kumar, B., Koul, S., Maroni, P. \& Koul, H., (2009) Oxidative stress in prostate cancer. Cancer Lett. 282: 125-36.

7. Cai, T., Santi, R., Tamanini, I., Galli, I., Perletti, G. \& Bjerklund, T., (2019) Current knowledge of the potential links between inflammation and prostate cancer. In. J. Mol. Sci. 20 (15): 3833.

8. Bajic, P., Dornbier, R., Doshi, C., Wolfe, A., Farooq, A. \& Bresler, L., (2019) Implications of the Genitourinary microbiota in prostatic disease. Curr. Urol. Rep. 20 (7): 34.

9. Heras, C., Gutiérrez, S. \& Serrano, G., (2016) Chronic bacterial prostatitis. Clinical and microbiological study of 332 cases. Med. Clin., (Barc). 147: 144-147.

10. Papeš, D., Pasini, M. \& Jerončić, A., (2017) Detection of sexually transmitted pathogens in patients with chronic prostatitis/chronic pelvic pain: A prospective clinical study. Int. J. STD. AIDS., 28: 613-615.

11. Breuggmannl, H. \& Al-Zeer, M., (2020) Bacterial signatures and their inflammatory potentials associated with prostate cancer. $J$. Path., Micro. and Immuno. APMIS, 128: 80-91.

12. Katongole, P., Obondo, J., Sande, S., Joloba, M., Steven, J., Reynolds, R. \& Niyonzima, N., (2020) The human microbiome and its link in prostate cancer risk and pathogenesis. Inf. Agents and Cancer. 15: 53.

13. Cavarretta, I., Ferrarese, R., Cazzaniga, W., Saita, D., Lucianò, R. \& Ceresola, E., (2017) The microbiome of the prostate tumor microenvironment. Eur. Urol., 72 (4):625-31.

14. Shrestha, E., White, J., Yu, S-H., Kulac, I., Ertunc, O. \& De Marzo, A., (2018) Profiling the urinary microbiome in men with positive versus negative biopsies for prostate Cancer. J. Urol., 199 (1): 161-71.

15. Alanee, S., El-Zawahry, A., Dynda, D., Dabaja, A., McVary, K. \& Karr, M., (2018) A prospective study to examine the association of the urinary and fecal microbiota with prostate cancer diagnosis after transrectal biopsy of the prostate using 16sRNA gene analysis. Prostate, 79 (1): 81-7.

16. Liss, M., White, J., Goros, M., Gelfond, J., Leach, R. \& JohnsonPais, T., (2018) Metabolic biosynthesis pathways identified from fecal microbiome associated with prostate cancer. Eur. Urol. 74: 575-582.

17. Sfanos, K., Sauvageot, J., Fedor, H., Dick, J., De Marzo, A. \& Isaacs, W., (2008) A molecular analysis of prokaryotic and viral DNA sequences in prostate tissue from patients with prostate cancer indicates the presence of multiple and diverse microorganisms. Prostate, 68: 306-20.

18. Eisenhofer, R., Minich, J., Marotz, C., Cooper, A., Knight, R. \& Weyrich, L., (2019) Contamination in low microbial biomass 
microbiome studies: Issues and recommendations. Trends Micro. 27: $105-117$.

19. Sfanos, K., Isaacs, W. \& De Marzo, A., (2013) Infections and inflammation in prostate cancer. Am. J. Clin. Exp. Urol. 1: 3-11.

20. Yu, H., Meng, H., Zhou, F., Ni, X., Shen, S. \& Das, U., (2015) Urinary microbiota in patients with prostate cancer and benign prostatic hyperplasia. Arch. Med. Sci. 2: 385-94.

21. Terlizzi, M., Gribaudo, G. \& Maffei, M., (2017) Uropathogenic Escherichia coli (UPEC) infections: Virulence factors, bladder responses, antibiotic, and non-antibiotic antimicrobial strategies. Front Micro. 8: 1566.

22. Porter, C., Shrestha, E., Peiffer, L. \& Sfanos, K., (2018) The microbiome in prostate inflammation and prostate cancer. Prostate Cancer Prostatic Dis. 21: 345-354.

23. Hanash, K., Al-Othaimeen, A., Kattan, S., Lindstedt, E. \& AlZahrani, H., (2000) Prostatic carcinoma: A nutritional disease? Conflicting data from the Kingdom of Saudi Arabia. J. Urol. 164: 1570-1572.

24. National Cancer Registry. Cancer incidence in Saudi Arabia 19971998 report. Riyadh (KSA): Ministry of Health; 2001.

25. Rabah, D. \& Arafa, M., (2010) Prostate cancer screening in Saudi population: An explanatory trial study. Prostate Cancer Prostatic Dis. 13: 191-194.
26. Areej M. Al Nemer, MD and Reem B. Aldamanhori, (2015) Prostatic diseases under focus in a university hospital in Eastern Saudi Arabia. Saudi Med J. 36 (11): 1319-1323.

27. Yi, M., Haiyang, M., Tan, M. \& Xuedong, M., (2020) Screening for chronic prostatitis pathogens using high-throughput nextgeneration sequencing. The Prostate, 80: 577-587.

28. Sherrard, J., Wilson, J., Donders, G., Mendling, W. \& Jensen, J., (2018) European (IUSTI/WHO) International Union against sexually transmitted infections (IUSTI) World Health Organisation (WHO) guideline on the management of vaginal discharge. Int. J. STD, AIDS, 2018; 29 (13): 1258-1272.

29. Nishant, T. \& Amit, S., (2020) Gram Staining. Treasure Island (FL): NCBI. StatPearls.

30. Manickam, K., Karlowsky, J. \& Adam, H., (2013) CHROMagar Orientation medium reduces urine culture workload. J. Clin. Micro. 51: 1179-1183.

31. Deng, J., Fu, L., Wang, R., Yu, N., Ding, X., et al. (2014) Comparison of MALDI-TOF MS, gene sequencing and the Vitek 2 for identification of seventy-three clinical isolates of enteropathogens. J. Thorac. Dis. 6: 539.

32. Khan, H., (2006) SCEW: A Microsoft Excel add-in for easy creation of survival curves, Comput. Meth. Prog. Biomed. 83: 1217.
This work is licensed under Creative Commons Attribution 4.0 License

To Submit Your Article Click Here: Submit Manuscript

DOI: $10.31579 / 2766-2314 / 022$
Ready to submit your research? Choose Auctores and benefit from:

* fast, convenient online submission

* rigorous peer review by experienced research in your field

* rapid publication on acceptance

* authors retain copyrights

* unique DOI for all articles

* immediate, unrestricted online access

At Auctores, research is always in progress.

Learn more www.auctoresonline.org/journals/biotechnology-andbioprocessing- 